\title{
Imagens da fama: abrindo os álbuns de fotografias do mercado erótico popular brasileiro
}

Raphael Bispo*

\section{Resumo}

A imagem estática adquiriu um significado essencial para a circulação de erotismos ligados às chacretes, as antigas dançarinas de palco de Chacrinha, programa da rede de TV brasileira, que serão foco deste artigo. 0 texto analisa uma série de fotografias que tais dançarinas utilizavam para a autopromoção de seus serviços profissionais. 0 trabalho procura explorar que 0 ato de tirar fotografias era uma das melhores oportunidades para as dançarinas desenvolverem suas habilidades em torno das técnicas corporais que lhes eram exigidas. E mais: era através do ato fotográfico que as chacretes buscavam o prestígio e a singularização no instável mercado erótico e do entretenimento dos anos 1970.

\section{Palavras-chave}

Carreiras artísticas. Gênero e Sexualidade. Televisão.

\begin{abstract}
The static image acquired an essential meaning for the circulation of eroticism connected to the chacretes. These old stage dancers in the Cachrinha show will be the focus of this article. The text analyzes a series of pictures which such dancers used to promote their professional services. The work intends to explore that the act of taking pictures was one of the best opportunities for the dancers to develop their abilities regarding the body techniques demanded of them. And more, it was through the photographic act that the chacretes aimed for prestige and singularity in the unstable erotic and entertainment markets of the 1970s.
\end{abstract}

\section{Keywords}

Artistic carrers. Gender and sexuality. Television.

\footnotetext{
* Raphael Bispo é professor Adjunto da Universidade Federal de Juiz de Fora (UFJF); Doutor em Antropologia Social pelo Museu Nacional (MN) - Universidade Federal do Rio de Janeiro (UFRJ); e pesquisador associado do Centro de Estudos Sociais Aplicados (CESAP) do Instituto Universitário do Estado do Rio de Janeiro (IUPERJ/ UCAM). E-mail: raphaelbispo83@gmail.com.
} 


\section{Introdução}

Durante o início dos anos 1970, um dos maiores apresentadores de televisão do Brasil na época, Abelardo Barbosa, o Chacrinha, foi o primeiro show man a se valer do recurso de exibir belas, jovens e sensuais dançarinas a fim de fomentar a audiência de seus programas, tanto na Rede Globo quanto nas demais emissoras pelas quais passou posteriormente. As chacretes - como ficou conhecido o corpo de baile que compôs durante cerca de vinte anos os programas de auditório desse apresentador-clown - adquiriram relativa notoriedade e tornaram-se figuras-chaves para a compreensão de uma linguagem audiovisual de marca popular no âmbito da televisão.

Nesse sentido, este artigo é resultado de uma pesquisa de campo realizada ao longo de dois anos de maneira esparsa (2010-2012) junto a essas antigas dançarinas, que hoje têm cerca de sessenta e cinco anos as mais velhas. $\mathrm{O}$ trabalho de campo foi feito na cidade do Rio de Janeiro, pelos mais diferentes bairros em que habitam as chacretes, numa busca em acompanhar o dia-adia de algumas delas. A pesquisa culminou com a redação de minha tese de doutorado (BISPO, 2016), que se tornou um relato da trajetória de vida da primeira geração de chacretes.

Durante minhas conversas com elas sobre suas experiências artísticas, percebia que diferentes tipos de imagem adquiriram um significado especial para a circulação de erotismos e a obtenção do renome, principalmente na maneira como se portavam diante das câmeras de televisão. Como demonstrei em outros textos (BISPO 2012; 2014; 2015), o sucesso das chacretes sempre esteve associado à necessária fabricação de uma performance de gênero hiperfeminina por parte dessas mulheres. A dança cênica e midiatizada delas, executada durante os programas de Chacrinha para uma ampla e diversificada plateia de telespectadores, tinha como proposta performática construir tais girls como mais mulheres do que qualquer outra mulher, parafraseando Perlongher (2008; p.100), visto que exageravam e dramatizavam a feminilidade mais convencional em suas apresentações borrando ou mesmo reificando certas fronteiras de gênero e da sexualidade mais hegemônicas -, atitude essa que nomeei nesses trabalhos anteriores de performance de superfêmea.

Isso porque, seguindo Butler (2003; p.194), pode-se dizer que tais performances exageradas das chacretes denunciavam o quanto o feminino/ ser mulher não é algo tão estável e ontológico assim, mas fabricações sustentadas por signos corpóreos e outros meios discursivos. Nos programas 
de auditório, as fabricações do feminino se davam particularmente na forma como as mulheres interagiam no palco. Suas habilidades performáticas de superfêmea, em última instância, eram provas de sua efetiva capacidade para ser chacrete e obter sucesso com a atividade. Veremos ao longo deste artigo, todavia, que fotografias impressas também foram essenciais para a construção desse tipo específico de performance. Isso porque pude perceber que a construção da superfêmea para as câmeras de vídeo era algo ainda considerado difícil, "complicado", devido aos primeiros contatos que elas estabeleciam com tal tecnologia em seu dia-a-dia. A fotografia sempre foi um recurso de incitação dos sentidos pelas chacretes por ser uma tecnologia há mais tempo difundida. Era mais fácil fazer-se superfêmea pelas imagens estáticas do que através das audiovisuais, em movimento.

Outra coisa que me chamou muito a atenção ao longo de minha pesquisa de campo com as chacretes foram os inúmeros passeios etnográficos que acabei realizando com elas por revistas, jornais, fascículos de coleções, biografias, autobiografias, cartas, fotografias, vídeos ou qualquer outro tipo de reminiscência sobre a experiência de se ser uma chacrete nos anos 1970 . Afinal, elas não "existem" hoje tal como as vemos em vídeos dos programas de Chacrinha. Elas compõem um momento muito específico das comunicações de massa no Brasil. Logo, um mergulho dito mais "historiográfico" foi se tornando muito importante em minha pesquisa a fim de compreender essa experiência de ser uma chacrete nos anos 1970.

Os arquivos e coleções particulares das próprias dançarinas tornaramse assim essenciais. Algumas possuem ainda um vasto acervo sobre o seu passado de dançarina, focado, é claro, em suas carreiras. Muitas possuem reminiscências escritas como cartas e autobiografias guardadas com cuidado em prateleiras empoeiradas. A vasta quantidade de material que algumas possuem, quando comparada a de amigas, já nos indica o quanto umas conseguiam mais espaço na imprensa em geral do que outras. Além disso, tais dançarinas "com arquivos" conseguiram manter praticamente intacto quase todo o material que recolheram. A manutenção durante mais de quarenta anos de todo o acervo não é algo fácil por esbarrar, por exemplo, nas tentativas de apagamento de seus passados por parte de maridos ou demais parentes. São várias as chacretes que tiveram ao longo da vida seus recortes incinerados por cônjuges. Sendo assim, procurei utilizar na pesquisa todo o material que elas compartilhavam comigo a fim de contarem suas vidas e que nos permitem não esgotar mas, sim, recompor de forma caleidoscópica alguns rastros dessas trajetórias heterogêneas. Tais textos e imagens antigos 
que emergiam em campo assumem neste trabalho o sentido de "inscrições objetivadas" proposto por Kofes (2001; p. 21), não por serem efetivamente mais objetivos do que certos relatos orais supostamente "subjetivos", enviesados, mas, sim, por preservarem melhor certa temporalidade difícil de ser captada em outros registros, tornando-se referências básicas para percebermos as dançarinas em seu auge nos anos 1970.

Tendo isso claro, este artigo procura analisar uma série de fotografias que tais dançarinas utilizavam para a autopromoção de seus serviços, presentes nesses arquivos pessoais. Trata-se de um álbum profissional composto por um conjunto mínimo de seis fotografias e que servia como um "curriculum imagético" (MARTINEZ, 2004; p.217) das chacretes. Serão analisadas também imagens delas exibidas em revistas eróticas da época, como a Status e a Revista do Homem. Ao final do artigo, veremos como as próprias dançarinas falam hoje sobre suas imagens e reportagens midiáticas de quarenta anos atrás. O artigo procura explorar que tirar fotografias era uma das melhores oportunidades para as dançarinas desenvolverem suas habilidades em torno das "técnicas corporais" (MAUSS, 2003) que lhes eram exigidas enquanto superfêmeas. E mais: era através do ato fotográfico que as chacretes buscavam o prestígio e a singularização no instável mercado erótico e do entretenimento dos anos 1970.

\section{Tecnologias Imagéticas e Performances de Superfêmea}

As chacretes possuíam uma força de comunicação tão intensa quanto era a sua imagem no conjunto do espetáculo televisivo comandado pelo Velho Guerreiro em programas como a Discoteca do Chacrinha e o Cassino do Chacrinha. A dança era sua melhor forma de interação com a plateia, seja o auditório propriamente dito, seja quem lhes assistia pela TV. No entanto, é preciso atentar para as peculiaridades dessa dança. Isso porque ela era elaborada numa articulação com a tecnologia televisiva. Dançava-se para as câmeras, num cenário montado em um estúdio de gravação, tudo disposto e organizado com a finalidade última de se transmitirem imagens por meio de antenas e sinais de longa distância. Quando Haraway (2009; p.76) formula a expressão "mulheres no circuito integrado", ela procura justamente aludir às configurações das dinâmicas sociais que passam cada vez mais a serem mediadas pelas novas tecnologias. As mulheres e suas práticas cotidianas são reestruturadas por meio das "relações sociais da ciência e tecnologia", 
articulação esta que acaba por compor significados específicos a seus corpos. Seguindo Haraway, a dança das chacretes precisa ser compreendida em sua integração a um circuito sociotécnico emaranhado de linguagens audiovisuais e técnicas de gravação próprias, cuja centralidade das dinâmicas de funcionamento do maquinário de filmografia repercutia diretamente na forma como se apresentavam, se comunicavam e davam significados aos seus corpos. As chacretes se faziam nas tecnologias de transmissão televisivas.

Isso ocorre justamente porque o período histórico que vai do final dos 1960 até meados da década de 1970 pode ser compreendido como um momento de grande relevância para a consolidação de uma efetiva e atuante indústria cultural no Brasil. Anteriormente, já produzíamos alguns filmes, editávamos poucos livros e ouvíamos certas músicas pelo rádio. Porém, as condições socioeconômicas do país durante tal época específica - sob os auspícios de um projeto político de integrar a nação por parte da ditadura militar vigente - estimularam o crescimento de um diversificado mercado de consumo de bens culturais até então nunca visto (CAPARELLI, 1982; ORTIZ, 1988). Deixávamos para trás a incipiente e um tanto amadora iniciativa de poucos empresários na área do consumo cultural para a solidificação de um amplo mercado do entretenimento, com bases lucrativas e de impacto na vida da população. A televisão foi, em boa medida, a força motora responsável por dinamizar a cultura popular de massa no país. As primeiras transmissões foram realizadas, em 1950, pela TV Tupi, de Assis Chateaubriand, ainda bastante atreladas às logísticas do rádio e do teatro (SIMÕES, 1986). Porém, já no início dos anos 1970, graças principalmente às investidas modernizadoras implementadas pela Rede Globo, tais transmissões viriam adquirir características próprias e um alto grau de profissionalismo (KEHL, 1986).

As tecnologias televisivas, que nos anos 1950/ 1960 atingiam um número reduzido de pessoas, passavam na década em que as chacretes foram estrelas por uma ampla expansão em termos de produção, distribuição e consumo. Em 1970, já existiam cerca de 4 milhões e 259 mil domicílios com aparelhos de televisão, o que significa que $56 \%$ da população era atingida de alguma forma pelo veículo (ORTIZ, 1988; p.130). No entanto, essa moderna tecnologia relativamente consolidada ainda era "novidade" para muitos indivíduos, já que o hábito de ver TV sedimentar-se-ia ao longo dos tempos. O videoteipe difundiu-se nesse período e garantiu uma circulação mais ampla pelo país, principalmente, das telenovelas, deixando concentrado nas grandes metrópoles os programas de auditório cujo "ao vivo" era fundamental para a 
sensação de euforia a ser passada ao público.

Boa parte das apresentações das chacretes pertencentes à primeira geração foi efetuada sem o auxílio de videoteipes. Dançava-se para as câmeras e só, quase nunca entravam em contato com as imagens que produziam para os telespectadores. Mesmo com a introdução de um sistema nacional de microondas interligando todo o território em 1968, através da Embratel (ORTIZ, 1988; p.118), o "ao vivo" permanecia sendo mais barato e valorizado para os auditórios. Se hoje a experiência dos sujeitos diante de imagens de si em movimento é quase que banalizada, o mesmo não se dava para as chacretes dos anos 1970. Havia a necessidade de uma aprendizagem constante, a fim de se saber lidar melhor com as tecnologias de gravação em movimento. Nas lembranças da chacrete Índia Potira, por exemplo, nas conversas gravadas que tecíamos, a fim de rememorar o passado, fica muito claro o quanto a dança televisionada em seu início era mais um tipo de dança como outra qualquer e que, aos poucos, a chacrete foi conhecendo a tecnologia específica ligada à TV e produzindo movimentos pertinentes ao veículo:

"Então como eu já fazia os clubes e tudo isso, foi aonde eu tinha que ficar nervosa. Depois a gente fazia apresentação em TV. Era como se fosse em clube. A gente não dava a mínima importância pra aquela tela que estava na nossa frente. Que a gente não tinha noção, bem dizer, do que era, entendeu? E eu depois não tinha oportunidade de me ver porque eu não tinha televisão. Então eu sempre trabalhei e não tinha a oportunidade de me ver. Só depois quando eu comecei a dançar na Tupi como bailarina profissional... Nem bailarina profissional, que minha mãe não tinha ainda televisão... Como atriz, que eu já morava sozinha, que eu tinha televisão, porque eu fui, antes de eu ter televisão, a gente via no VT. Acabava a gravação e 'Valeu!'. Aí corria todo mundo pro VT pra gente assistir. Aí que eu comecei a me assistir, fazer uma dança pro vídeo e tal".

Assim, se o modo de funcionamento da TV era novidade a ser destrinchada, foi por meio das fotografias, isto é, das imagens estáticas fixadas em uma superfície sensível, que as chacretes mais souberam estimular erotismos e aprimorar técnicas corporais. Mesmo sendo as percursoras da dança no vídeo, em seus depoimentos as chacretes sempre me lembravam de que era por meio das fotografias que "se sentiam mais à vontade" para executarem suas performances. Se a construção da superfêmea para as câmeras de vídeo era algo ainda complicado e inusitado devido aos primeiros contatos que 
estabeleciam com tal tecnologia em seu dia a dia, a fotografia sempre foi um recurso de incitação dos sentidos, por ser uma técnica há mais tempo difundida e da qual elas já haviam feito múltiplos usos bem antes de chegarem à TV.

Para a autopromoção de seus serviços, as chacretes não abriam mão de possuírem em todo lugar que iam um conjunto de fotografias de si mesmas feitas por especialistas, tiradas em estúdios fotográficos ou em ambientes propícios. Esse álbum profissional era composto por um conjunto mínimo de seis fotografias e servia como um "cartão de visitas" e, ao mesmo tempo, um "curriculum imagético" das dançarinas, algo que tempos depois o mundo da moda viria a consagrar com o nome de book (MARTINEZ, 2004; p.217). Por meio desse repertório de imagens estáticas, as chacretes divulgavam seus "serviços" entre produtores, diretores e jornalistas. Mais íntimas das câmeras fotográficas do que das televisivas, disseminavam melhor seus serviços por meio dessas formas imagéticas mais tradicionais. Em muitos casos, era comum possuírem cópias em tamanho reduzido de tais fotografias, a serem distribuídas entre amigas de trabalho ou deixadas em agências ou estúdios com um número de telefone atrás escrito à mão ou carimbado para contatos.

As fotos selecionadas buscavam "vender" seus serviços de dançarina aos interessados. Havia uma substituição periódica por novas fotografias no álbum, conforme os trabalhos eram realizados e a carreira avançava. O responsável pelas imagens - a "assinatura" das fotos - garantia um diferencial, sendo elogiadas até hoje as dançarinas que "conseguiram" ser fotografadas pelos mais renomados do mercado. A ideia de "conseguir" uma foto assinada revela-nos as etapas e inconstâncias da carreira. Aliás, a improvisação e a tentativa de montar um álbum com poucos recursos era uma saída encontrada por muitas diante das dificuldades recorrentes da ocupação. Deparei-me com inúmeros conjuntos de fotos menos profissionais tirados em locais públicos, ao término de shows, diante de paisagens ou em parques, até mesmo dentro de casa, geralmente produzidos por um amigo ou conhecido mais talentoso do meio artístico. Tais características conferiam às fotos uma marcação distinta: a de que a dançarina estava ou em início de carreira ou não era tão requisitada assim pelo mercado por ter fotos tão "pobres". A meta era tornar as mais provisórias possíveis tais imagens, sendo substituídas bem rapidamente pelas confeccionadas em estúdio. 
As fotos de divulgação do trabalho de Índia Potira e Lucinha Apache Fonte: Acervo pessoal de Índia Potira
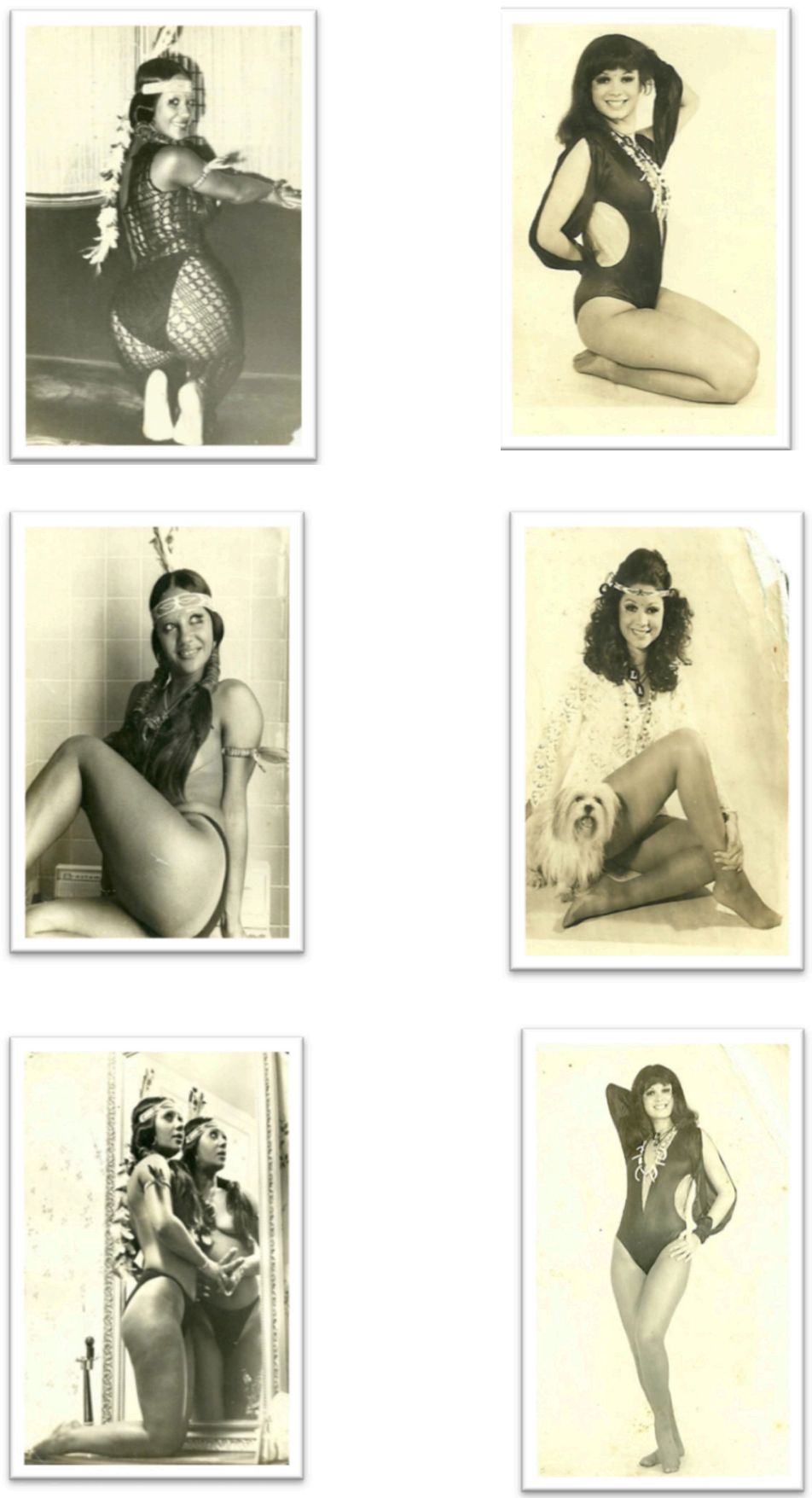
As fotos de divulgação do trabalho de Edilma Campos e Beth Boné Fonte: Acervo pessoal de Edilma Campos e Beth Boné
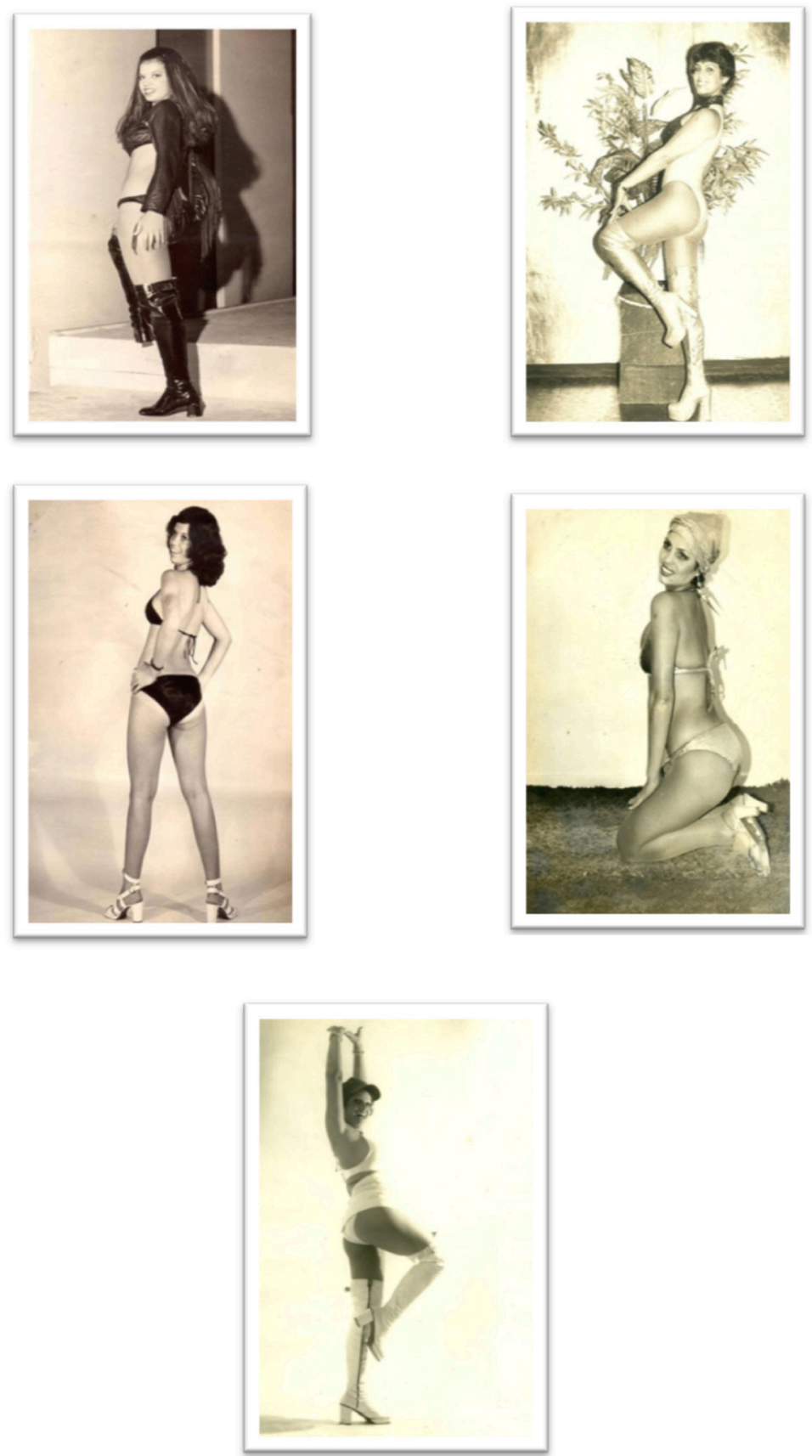
Em sua consagrada obra Naven, Bateson (2008; p.199) revela-nos o quanto a fotografia e o próprio ato de produzi-las provocava nos iatmuls a manifestação explícita dos ethos que compõem as contrastivas diferenças entre os gêneros no grupo. O estilo guerreiro e orgulhoso dos homens da tribo manifestava-se com bastante constância sob as condições experimentais produzidas ao se apontar uma câmera para um indivíduo. O mesmo poderia ser pensado para a dupla tendência do ethos feminino observada pelo autor: ora cooperativas e humildes nas fotos feitas em certos contextos privados; ora orgulhosas e ativas quando, bem vestidas, as mulheres posavam às lentes no espaço público. As imagens captavam com perfeição as "personalidades" e "temperamentos" que permeavam os "sexos" iatmuls, revelando o quanto os marcadores de gênero e da sexualidade diziam muito sobre a experiência de vida daquela tribo da Nova Guiné nos anos 1930, até mesmo por meio de simples atos fotográficos.

Acredito que, respeitando-se os propósitos específicos das imagens e seus contextos históricos, pode-se afirmar que a hiperfemilidade das chacretes fazia-se captar também com bastante precisão quando elas percebiam o olhar da câmera sobre si durante a confecção de fotografias profissionais. Como afirmaram Bourdieu e Bourdieu (2006; p.38) sobre o exercício de alteridade que é o momento fotográfico, "ao olhar para a pessoa que olha para mim (ou que me fotografa), ao preparar a minha postura, dou-me para ser visto como quero ser visto; dou a imagem de mim próprio que quero dar e, muito simplesmente, dou a minha imagem". Na verdade, essas atividades eram uma das melhores oportunidades para as dançarinas desenvolverem suas habilidades em torno das técnicas corporais que lhes eram exigidas enquanto dançarinas. Elas sempre me disseram que tirar fotos era uma atividade que as ajudava no desenvolvimento de gestos, expressões faciais

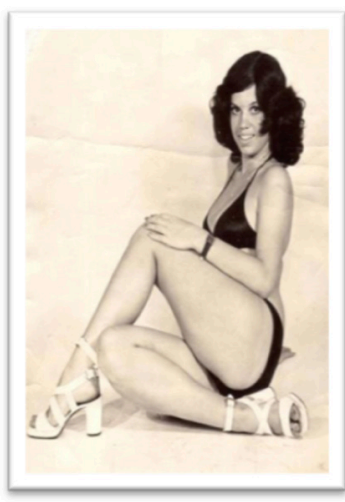
e corporais diferenciados, conforme a imagem de superfêmea.

Acompanhando várias séries de fotografias pertencentes aos rotativos álbuns de quatro chacretes (Edilma Campos, Beth Boné, Índia Potira e Lúcia Apache), notamos imageticamente essa disposição dos ethos, quando os sujeitos estão diante de câmeras tal como identificada por Bateson. A maioria das fotos profissionais era tirada com uma tela em branco ao fundo, o que permite que se veja a chacrete em destaque. Ela era instalada no centro 
da imagem. Não se fotografa apenas o tronco, o rosto ou detalhes corporais. Era preciso captá-las por inteiro, em todas as suas dimensões, e a tela permitia esse efeito. A brancura do entorno fotográfico garante a concentração de quem observa a imagem no complexo trabalho de fotogenia efetuado pela equipe para aquela cena, já que se realçam poses, gestos e comportamentos por meio desse artifício. Ao utilizarem roupas sumárias como biquínis, maiôs, shorts curtos, lingeries, vestidos decotados e roupas transparentes, as chacretes destacavam ainda mais seus contornos corporais e facilitavam a identificação de suas medidas, quando estas já não estavam anotadas na parte de trás da fotografia (busto, cintura, quadril e coxas).

As principais poses efetuadas aproximam-se imageticamente daquilo que as fofocas escritas na imprensa popular já difundiam simbolicamente, a combinação entre um agressivo erotismo da mulher "devoradora de homens" com uma submissa domesticidade. As jovens promovem, quando fotografadas, uma "ritualização da feminilidade" (GOFFMAN, 1977; p.38), na medida em que, por mais diferentes que sejam as poses e gestos adotados, bem como infinita seja a variabilidade de configurações cênicas possíveis de serem formuladas pela equipe, há sempre recorrências estruturais que nos indicam algumas reificações das normativas de gênero e sexualidade presentes em nossa sociedade. Isso pode ser verificado, por exemplo, nas fotos nas quais as chacretes encontram-se ora agachadas, dispersas pelo chão do estúdio, ora em pé, em poses altaneiras. Por mais diferentes que sejam tais imagens, uma vez que exigem dos profissionais recursos fotográficos antagônicos, elas aproximam-se estruturalmente uma da outra devido aos sentidos ali subjacentes sustentados pelos signos corpóreos e outros meios discursivos que eclodem de tais narrativas imagéticas.

Assim, o agachamento sugere desde uma inata submissão e dependência femininaàquele que aobserva-pressupondo ser esse público primordialmente de homens heterossexuais - até a disponibilidade sexual, a indicação de estar preparada para o coito por meio da adoção de uma postura passiva, de espera pela penetração. Nesse caso, percebemos o uso do recurso do plongée pelo fotógrafo, um tipo de enquadramento em que a câmera capta a modelo de cima para baixo, produzindo um efeito de diminuição da jovem. Esse "mergulho" do enquadramento é sugestivo para compor a espera sexual corporificada e inferiorizada da chacrete. Ele se faz por meio de tais gestos combinados aos recursos visuais, como se o espectador estivesse prestes a se jogar sobre a girl à sua disposição.

As fotos em pé faziam uso do contra-plongée na maioria das vezes, quando 
a câmera enquadra o objeto de baixo para cima. Isso engrandecia a chacrete na imagem, gerando uma sensação de superioridade dela em relação ao observador. Ora, tal engrandecimento não é alusivo a uma posição privilegiada delas na hierarquia social, mas, sim, de um enaltecimento da superfêmea que elas se tornam enquanto chacretes. Por meio desse recurso, realçavam-se as coxas, bundas e pernas, se possível permitia-se até mesmo mostrar parte de suas roupas íntimas. A chacrete visivelmente tornava-se maior do que todas as mulheres. O corpo alongava-se nesse enquadramento e não se contraia como quando estavam agachadas. Porém, tais disposições cênicas entre plongées e contra-plongées não são tão antagônicas assim porque sempre acabam remetendo, por meio dessas "repetições de atos estilizados" (BUTLER, 2003; p.48), à eminência do intercurso sexual e à disponibilidade das dançarinas para a "safadeza". As fotografias, portanto, "fazem gênero", segundo Butler (2003), ou "ritualizam feminilidades", nos termos de Goffman (1977; p.38), mesmo diante de distintas maneiras de serem compostas, porque os signos corporais incentivados nas imagens performatizam a todo instante as normas binárias de gênero e das relações sexuais que marcam nossa vivência social.

Os gestos mais recorrentes nas fotos também reforçam milimetricamente tais performances que fazem gênero: além dos olhares e sorrisos provocativos para a câmera, a maioria destaca o bumbum das chacretes, o grande protagonista de tal encenação ritualizada. Assim, posa-se de costas ou de lado, quase sempre. As regiões genitais também ganham destaque, mas não superam em recorrência o apreço dado às nádegas pelos fotógrafos. Era comum conseguir realçar as partes da frente da chacrete colocando os braços por trás da cabeça, indicando a disposição da modelo em mostrar ao espectador a sua "área" íntima. Esconder os braços também garantia maior exibição do corpo por inteiro. Logo, tais poses e gestos sempre sugerem as partes corporais que podem causar maior excitação em quem as vê. As fotografias, portanto, permitem observar os "pequenos comportamentos" que fazem gênero no cotidiano, mas são difíceis de serem captados devido as suas "microfuncionalidades" dispersas e fortuitas (GOFFMAN, 1977; p.34).

\section{Passeando pelas Revistas Eróticas}

Outro conjunto de fotografias das chacretes que garantia as circulações de erotismos podia ser visualizado nos periódicos voltados "para adultos" dos anos 1970 e 1980. As dançarinas abasteciam regularmente o mercado de 
modelos que posavam nuas ou seminuas. Apesar da disposição maior dos editores em mostrar aos leitores cenas de nudez feminina e, não raro, a simulação de relações sexuais, era a heterogeneidade de como se efetivava essa abordagem que diferenciava tais publicações entre si.

As chacretes tornaram-se referências para as revistas masculinas que surgiam nos anos 1970 na esteira da diversificação das publicações seriadas e do aumento no volume e dimensão do mercado de bens culturais. O setor de publicações cresceu em um ritmo vertiginoso, quadruplicando a partir de 1965 o número de exemplares vendidos no país em um intervalo temporal de apenas dez anos, além de trazer à tona uma grande variedade de títulos e linhas editoriais, voltados para a ideia, a partir de então em voga na indústria cultural, de que existiam públicos especializados que consomem produtos diretamente produzidos para eles (ORTIZ, 1988; p.123). Status (Editora Três), Ele Ẽ Ela (Bloch), Revista do Homem (posteriormente chamada de Playboy, da Abril) e Homem (Idéia Editorial) tornaram-se as mais vendidas "revistas masculinas". Todas elas tiveram chacretes estampadas em sua capa ou miolo em diferentes tempos. Tais periódicos eram produzidos pelas grandes editoras que, diante do sucesso conquistado pelas revistas de "mulher pelada" produzidas quase que amadoramente pelas rotativas das pequenas empresas, decidiram investir no filão do mercado do sexo, passando a valorizar a nudez de brasileiras. Essas revistas consolidaram-se no mercado pelo fato de terem sido aquelas que tiraram a roupa das estrelas da televisão e das celebridades do momento ou que apostavam na descoberta de símbolos sexuais, garotas que, de suas páginas, saiam do anonimato para a fama. As chacretes, portanto, ocuparam espaços hegemônicos nesse segmento. Se na TV eram coadjuvantes, nas revistas eróticas tornaram-se finalmente protagonistas.

Tal entrada das grandes editoras no mercado erótico deixou de lado as fotos de nus oriundas das agências internacionais, recorrentes nas publicações mais populares e baratas, em prol de uma "fabricação nacional". Essa autossuficiência estimulou o desenvolvimento de linhas editoriais que procuravam distinguir as novas publicações perante a concorrência "menor". Essas novas linhas tomaram como referência de suas qualidades as performances pelas quais expunham as mulheres em suas páginas considerados estilos "não vulgares" ou "obscenos" de nudez - e as formas de composição da foto, utilizando-se das mais variadas técnicas ditas artísticas (GONÇALO JR., 2010). A proposta era a de consolidar a perspectiva de que não havia nada de transgressor e muito menos uma "intenção deliberada de 
violar tabus morais e sociais" (GREGORI, 2003; p.94) nas revistas. Insinuavase nessa clara intenção editorial e de conquista de mercado a reafirmação de uma fronteira recorrente no imaginário ocidental entre as proibitivas e execráveis imagens "pornográficas" (um conceito mais carnal, sensorial e explícito da nudez) em oposição às aceitáveis imagens "eróticas", que exibiriam o nu para o deleite e elogio do belo, algo que tenderia "ao sublime, espiritualizado, delicado, sentimental e sugestivo" (LEITE JR., 2006; p.32). Essa operação clarifica-se na nítida tentativa de demarcação de fronteiras presente na carta de um profissional da Editora Abril em resposta a uma censura sofrida pela Revista do Homem em 1975: "a aludida determinação se deve ao acanalhamento da nudez feminina que revistas de outro nível têm criado, explorando-a em situações, posições e expressões de evidente lascívia, quando não grosseiramente fesceninas” (GONÇALO JR., 2010; p.249).

Na busca pela legitimidade cultural desses periódicos, apelava-se, portanto, para um apagamento do choque, uma neutralização das possíveis tensões que tais imagens poderiam suscitar socialmente, "um esforço claro de integração e não de subversão" (GREGORI, 2003; p.111). As revistas masculinas das grandes editoras sempre fizeram uso de termos autopromocionais, como "sofisticadas", "sem vulgaridades", "de bom gosto", "para um homem seletivo" etc., a fim de conquistar públicos de maior poder aquisitivo e ditos consumidores. Portanto, os periódicos das grandes editoras posicionavam-se no mercado construindo um "erotismo politicamente correto" (GREGORI, 2003; p.111), a fim de maximizar seus lucros e serem aceitos perante o público. A nudez é domesticada por meio dos recursos audiovisuais disponíveis; ela insinua-se, é sutil, mas a tensão sexual nunca é abertamente exibida. Afastase com isso do dito "pornográfico", supostamente recorrente nos impressos alternativos, em que as poses, ângulos e formas de disposição dos corpos são considerados obscenos por exibirem situações de libidinagem, de prazer sexual, de masturbação, ou mesmo cenas de sexo reais, sem subterfúgios.

Mesmo diante da ascensão da temática sexual "politicamente correta" ao cardápio de assuntos publicáveis nos anos 1970, tal assunto continuava a ser uma questão de "segurança nacional", fazendo com que os grandes editores também se vissem envolvidos por ofícios, memorandos e verificação prévia de conteúdo nas redações. A revista Status de setembro de 1975, cuja capa era a chacrete Sandra Mattera, foi uma das que mais sofreu restrições antes de chegar às bancas no âmbito das publicações da Editora Três. Segundo Gonçalo Jr. (2010; p.239), foi cobrada, a princípio por parte da censura prévia, a total proibição da circulação desse número com Mattera. Diante das 
negociações, permitiu-se circular quatro das dezesseis fotos programadas, sendo que Mattera deveria estar "vestida" em todas, sem "mamilos à mostra". Foi preciso um exercício gráfico, a fim de adaptar as imagens aos desígnios da censura. O nu frontal ou seu correlato eufemismo de "exibição dos pelos pubianos", aliás, era algo terminantemente proibido, sendo liberado apenas no ano de 1980, com a portaria do Governo Federal anunciando maior tolerância para manifestações artísticas em geral que fizessem uso do nu frontal (GONÇALO JR., 2010; p.373). Assim, os fotógrafos precisavam, durante o ato de tirar as fotos, ser criativos para produzirem imagens que insinuassem ao máximo os corpos das modelos sem esbarrar nas proibições tão taxativas da censura.

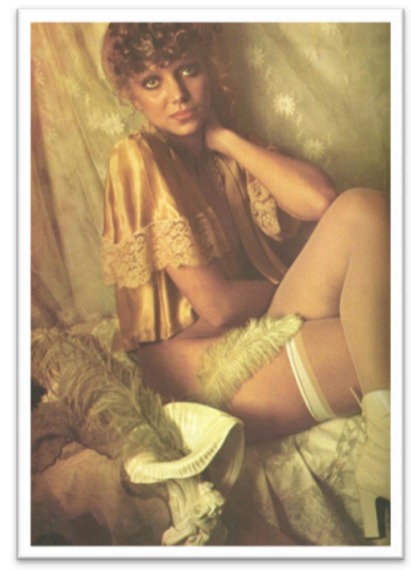

Sandra Mattera na Revista Status, em 1975

Fonte: Status, setembro de 1975 , n. 14, p. 72, acervo da Biblioteca Nacional

Um passeio pelos ensaios sensuais das chacretes nas revistas masculinas - e levando-se em conta esse contexto de conquista de mercado e censura federal dos anos 1970 - revela-nos outros enunciados sobre sexualidade e performances de gênero um tanto diferentes da superfêmea que temos visto até agora. A Status polêmica com Sandra, por exemplo, valorizou os traços fenotípicos europeus da chacrete, descendente de italianos, por meio de cenários e figurinos que aludiam às alcovas ou bordéis de final do século XIX. Plumas, cortinas, roupas com rendas e objetos de antiquário compõem a cena. As imagens são muito recatadas e parecem fazer referências às cocotes e cortesãs. Valorizam o rosto e os olhos da chacrete, ao invés das partes corporais inferiores. Sandra nunca esteve tão vestida publicamente 
quanto na revista voltada justamente para a exposição da nudez. Até na TV aparecia mais despudorada. No máximo, uma foto com as costas nuas, mas sem qualquer close do bumbum ou genitálias, e muito menos recursos estéticos, como o plongée ou contra-plongée. Se os gestos corporificados e rotineiramente praticados na cena pública sempre reverberam na imagem de mulher superexcitada, aqui esse lado é um tanto amainado, ganhando mais força o imaginário de fragilidade e docilidade femininas, sem qualquer conotação de atrevimento e volúpia sexual. Não há sorrisos, apenas uma rígida seriedade. Os jogos com as mãos no rosto ou por trás dos ombros sugerem uma timidez, como se quase escondessem a face diante daquela exposição. As pernas e o colo são as poucas partes corporais reveladas entre meias-calças e babados do figurino. Sem sombra de dúvidas, há uma preocupação da fotógrafa Marisa Alvarez Lima em fazer algo dito artístico, com "qualidades" estéticas e técnicas fotográficas originais.

Diante desse e de outros ensaios pela década de 1970 afora, percebemos que as chacretes eram mais superexcitadas nos espaços menos vigiados pela censura, tornando-se sublimes, delicadas e sentimentalizadas nas revistas masculinas. Mas é preciso ir além da atuação tópica do controle governamental e dimensionar os efeitos disciplinares por detrás desses periódicos. Afinal, advertenos Leite Jr. (2006; p.16), o mercado erótico legalizado e hegemônico, mais do que liberar a fruição dos prazeres, pode explicitar uma padronização dos desejos e uma domesticação dos corpos. Como visto, existe uma intenção candente dos editores das revistas masculinas mainstream em fazer de seus produtos algo que não constranja a moral sexual reinante, já que estão disponíveis a se adequarem e conquistarem espaços no mercado editorial.

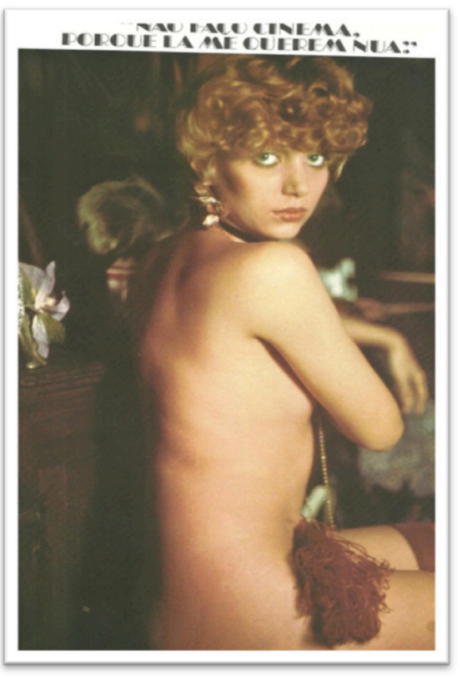
O comprometimento das revistas com uma moral hegemônica não é, portanto, um mero resultado da censura, mas também uma compreensão maior dos limites da exposição da nudez, do que é digno de ser visto e exposto. Isso reverbera em uma busca constante em não oferecer aos leitores imagens "sexualizadas", mas, sim "eróticas", “artísticas”, percorrendo um caminho paralelo, que é o da hipervalorização 
do puritanismo moral das modelos que se dispunham a aparecer nos ensaios. Seminuas, sim. Mas vulgares, nunca.

Isso se verifica com frequência nos textos que acompanhavam as fotografias. Não eram somente as imagens que apregoavam o comedimento comportamental de uma chacrete, mas os escritos que seguiam junto a elas também complementavam o libelo ao "erotismo politicamente correto" que se propunha a Status e outros títulos. A chamada principal do ensaio era "Sandra, à espera de um homem realmente interessante", e a matéria de uma página enfatizava a trajetória da dançarina, descrita como "um bom esquema de mulher" e "atraente e muito sexy, na base do felino, hoje sua figura elástica, saudável, e seu rosto de olhos grandes e verdes, são conhecidos de qualquer telespectador que se preze”. O interessante é perceber o espaço dado nessas apresentações às afirmativas que exaltam o seu interesse em não posar completamente pelada ("Só no cinema é que nunca acertei trabalho. É que sempre me quiseram nua, e nua não filmo") e sua timidez ("tímida e envergonhada por causa talvez de uma formação muito rígida e conservadora, de família de Vila Isabel, onde vivo até hoje"1). Dessa forma, tanto os textos quanto as imagens nas revistas oferecem sentidos complementares à proposta geral recorrente nas linhas editoriais de representar uma feminilidade limpa, legal e organizada. Todavia, é fato que a imagem não é o equivalente ao texto, "a capacidade despertadora da imagem não pode igualar a função enunciativa da linguagem" (SAMAIN, 2004; p.69). Somos conduzidos a compreender as fotografias como sendo representativas e ilustrativas desse erotismo plácido que os editores procuram imputar à revista. O texto tende sempre a preceder à imagem; recorremos a ele para buscar o sentido atribuído pelos produtores, e não o contrário.

"O texto conduz a imagem, a dirige. O texto induz a ver a imagem e, nela, a reencontrar o conceito antes formulado. A imagem é uma empregada inteligente e necessária: ela 'serve' a 'traduzir', a 'fazer entender', a 'justificar' aquilo que as palavras não consigam mostrar com tanta eficácia” (SAMAIN, 2004; p.70).

\footnotetext{
${ }^{1}$ Status, setembro de 1975, n. 14, p. 72, acervo da Biblioteca Nacional.
} 


\section{Conclusão}

Afim de concluir este artigo sobre as fotografias de divulgação das chacretes, gostaria de retomar aqui alguns dados de campo das conversas que tive com elas e que esclarecem o que as próprias pensam a respeito das imagens que tiraram mais de quarenta anos atrás. Existem duas categorias recorrentemente mencionadas por elas e que despontam como emblemáticas para compreendermos a forma como analisam a própria exposição nessas mídias: a "notícia" e a "fofoca".

A "notícia" consiste na narrativa midiática considerada por elas como "positiva". Ela pode ter uma marca meramente informativa, de compartilhamento com o público de questões sobre sua vida privada sem qualquer caráter avaliador ou crítico por parte do narrador. A "notícia" mais valorizada é aquela que menciona suas belezas, fala de seus corpos ou mesmo elogia suas atuações como dançarinas. É "notícia", portanto, todas as narrativas que não contem avaliações ou julgamentos de seus comportamentos, ou que as enaltecem, dignificando-as perante os outros, tal como essas fotografias mostradas ao longo do artigo, seja as de divulgação ou as das revistas eróticas.

Porém, muita "notícia" pode ser maliciosa, hostil e crítica às dançarinas, contendo dados equivocados ou mesmo mentirosos. Ainda assim, muitas não provocam um tipo de repulsa maior por parte delas nos dias de hoje, pelo contrário, trata-se de uma informação que, quando bem manipulada, pode ser bem vista. Exemplos desses textos são as ironias e maledicências sobre suas relações amorosas recorrentes na imprensa. Tais textos continuam sendo para elas "notícias", mesmo que tais malícias tencionem suas reputações e, em algum grau, façam com que se sintam ofendidas com isso.

Isso ocorre porque o sentido puramente positivo de certas informações não é uma condição necessária para a satisfação das chacretes com o que dizem sobre elas. "Falar mal", ser um tanto difamada, parece ser um acordo tácito que fazem consigo mesmas para angariar espaços. É constitutivo da persona-superfêmea ser em algum grau "mal-falada". As informações maliciosas compõem o repertório porque incitam os sentidos dos leitores, estimulam o erotismo. Ser "notícia" é importante, mesmo com leves toques de difamação. A fofoca dá status, insere as novatas no rol das dançarinas conhecidas. "Estar na boca do povo por bem ou por mal”, é vital. Logo, as dançarinas oferecem à categoria "notícia" um sentido amplo, açambarcando matérias e fotografias neutras, elogiosas (como as fotografias aqui mostradas) e até aquelas que 
elas mesmas percebem como sendo um tanto hostis a suas honras. "Falem bem ou falem mal, mas que falem de mim" é quase um mantra repetido por várias ainda hoje, apontando para suas negociações morais com o que é dito sobre suas vidas, o grau e o tipo de difamação que conseguem suportar e passarem incólumes.

Todavia, isso não significa a inexistência de limites acerca do que é possível ser dito. Nem toda difamação é bem-vinda. O julgamento mal recebido, as narrativas imagéticas depreciativas que abalam e impactam reputações são vistas como "fofoca". A "fofoca" não é qualquer circulação de informação sobre elas propriamente dita, mas aquela que exclusivamente machuca, é "mídia negativa", só causa aporrinhações e aborrecimentos. As reportagens de seus álbuns pessoais sobre consumo de drogas entre as chacretes são de longe o melhor exemplo de "fofoca". O consumo de "tóxicos" era um desses temas a serem rechaçados com veemência. Assim, em certas esferas, como as que remetem ao campo do gênero e da sexualidade, ser "mal-falada" pode ser uma situação positivizada por render frutos profissionais e contribuir para a performance de superfêmea. No entanto, a difamação por meio da pecha de "viciada" não é "notícia", mas "fofoca", por não condizer com aquilo que se espera socialmente delas como dançarinas.

O que tais lembranças e comentários das chacretes sobre suas imagens na imprensa em geral nos mostra também é uma constante "negociação da realidade" (VELHO, 2010) por parte delas com certas exigências em torno de suas personas hiperfemininas e o quanto elas próprias dominavam relativamente a forma como deveriam portar-se na mídia, incentivando elas mesmas também a imagem erótica da superfêmea. Ao adentrarem o show business, as jovens deparavam-se com um conjunto de processos e procedimentos para ser uma chacrete que as faziam dialogar a todo tempo com os intempéries da ocupação, percebendo possíveis caminhos a serem seguidos e trocando informações entre si mesmas no sentido de como adquirir status e prestígio na carreira. $\mathrm{O}$ artista no contexto da indústria do entretenimento é um ser em constante diálogo com seus próprios limites e as exigências da estrutura de produção, devendo ser flexível o suficiente para satisfazer certas expectativas em torno de suas personas. Aparecer como nas fotografias mostradas ao longo deste texto era quase que uma obrigação para todas as chacretes.

A importância da circulação das chacretes pela mídia indica que a ocupação é efetuada por jovens mulheres das camadas populares em início de carreira, sendo o burburinho uma oportunidade para o encontro, 
as sociabilidades e a consolidação de redes profissionais. Os bastidores televisivos são, primordialmente, uma forma de se incluírem em uma rede de pessoas que ocupam posições privilegiadas na indústria cultural. Estar ali era conseguir informações, fazer amigos e ter acesso a pessoas importantes, além de ampliar o circuito de consumo. O próprio tempo de duração como chacrete liga-se ao bom tráfego por tais redes. Isso incita as jovens a uma constante busca por contatos e trocas. É preciso articular-se ao meio, conhecê-lo, saber com quem falar, inteirar-se dos eventos. Ser chacrete implica percorrer um universo variado de espaços e exigências. Além da dança, beleza e hiperfeminilidades, importam também as sociabilidades engendradas nos bastidores, que permitem estabelecer redes, amizades e caminhos que auxiliarão a um maior destaque.

Portanto, "estar na mídia", "aparecer" era um meio privilegiado para a ascensão das dançarinas a estratos sociais antes nunca frequentados, para a ultrapassagem das fronteiras das classes, enfim, para a abertura de suas vidas a um "novo mundo", marcado pelos "sonhos" e possibilidades de consumo. Estar nesses lugares antes nunca frequentados, junto com "pessoas finas e chiques", curtindo a vida de maneira um tanto despretensiosa e em ambientes envolvidos em uma aura de glamour e exceção, fazem com que elas se lembrem da aproximação com as artes de maneira saudosista. Isso nos revela também as novas possibilidades de vida e melhorias no seu dia-a-dia que o trabalho no mundo artístico possibilitou, pelo menos temporariamente. A vida artística era indicativo também de um momento em que puderam consumir como nunca, festejar e gozar a vida. As imagens de outrora são, de certa forma, instrumento de ostentação e signos da distinção social pela qual passavam por meio de suas carreiras essas mulheres oriundas das camadas populares dos grandes centros urbanos da década de 1970.

\section{Referência}

BATESON, Gregory. (2008). Naven. São Paulo: Edusp.

BISPO, Raphael.

(2016). Rainhas do Rebolado: carreiras artísticas e sensibilidades femininas no mundo televisivo. Rio de Janeiro : Mauad X/ Faperj.
(2015). Vivendo do Rebolado: feminilidades, corpos e erotismos no show business televisivo. Mana, v.21, n.2; p. 237-266.

(2014). Feminilidades a dedo: danças, performances e erotismos no show business televisivo. Aceno, v.1, n.2 ; p. 25-39. 
(2012). Gênero e carreiras artísticas na emergente indústria cultural brasileira. Comunicação e Sociedade, v.21; p. 79-94.

BOURDIEU, Pierre ; BOURDIEU, Marie-Claire. (2006). 0 camponês e a fotografia. Revista de Sociologia e Política, n. 26; p. 31-39.

BUTLER, Judith.

(2002). Cuerpos que importan: sobre los limites materiales y discursivos del 'sexo'. Buenos Aires: Paidós.

(2003). Problemas de gênero: feminismo e subversão da identidade. Rio de Janeiro: Civilização Brasileira.

CAPARELLI, Sérgio.

(1982). Televisão e Capitalismo no Brasil. Porto Alegre: L\&PM.

GOFFMAN, Erving.

(1977). La Ritualisation de la feminite. Actes de la Recherche em Sciences Sociales, n.14, v.1 ; p. 34-50.

GREGORI, Maria Filomena.

(2003). Relações de violência e erotismo. Cadernos Pagu, n. 20, v.1; p. 87-120.

HARAWAY, Donna.

(2009). Manifesto Ciborgue: ciência, tecnologia e feminismo-socialista no final do século XX. In: Donna Haraway et al. (Orgs.); Antropologia do ciborgue: as vertigens do pós-humano. Belo Horizonte: Autêntica.

JÚNIOR, Gonçalo.

(2010). Maria Erótica e o Clamor do Sexo: imprensa, pornografia, comunismo e censura na ditadura militar (1964-1985). São Paulo: Editoractiva.

LEITE JÚNIOR, Jorge.

(2006). Das maravilhas e prodigios sexuais: a pornografia "bizarra" como entretenimento. São Paulo: Annablume/ Fapesp.

KEHL, Maria Rita.

(1986). Eu vi um Brasil na TV. In: Inima Simões; Hari Kunzru; e Tomaz Tadeu et al. (Orgs.); Um país no ar: história da TV brasileira em três canais. São Paulo: Brasiliense/Funarte.
KOFES, Suely.

(2001). Uma trajetória, em narrativas. Campinas: Mercado das Letras.

MARTINEZ, Fabiana Jordão.

(2004). Experiência e (hiper)corporalidade entre modelos profissionais". Cadernos do IFCH, n.31; p. 211-234.

MAUSS, Marcel.

(2003). As técnicas do corpo. In: Marcel Mauss; Sociologia e Antropologia. São Paulo: Cosac Naify.

ORTIZ, Renato.

(1988). A moderna tradição brasileira. São Paulo: Brasiliense.

PERLONGHER, Néstor.

(2008). 0 negócio do michê: a prostituição viril em São Paulo. São Paulo: Fundação Perseu Abramo.

SAMAIN, Etienne.

(2004). Balinese Character (re)visitado. In: André Alves; Os Argonautas do Mangue. São Paulo: Imesp.

SIMÕES, Inimá.

(1986). TV à Chateaubriand. In: Inima Simões; Alcir Henrique da Costa; e Maria Rita Kehl (Orgs.); Um país no ar: história da TV brasileira em três canais. São Paulo: Brasiliense/ Funarte.

VELHO, Gilberto.

(2010). Metrópole, cosmopolitismo e mediação. Horizontes Antropológicos, n.33; p. 15-23.

\section{Recebido em}

setembro de 2015

\section{Aprovado em}

maio de 2016 